\title{
Determination of leadership styles of boxing trainers
}

\author{
Kayhan SERIN 1, Turgut KAPLAN 2 \\ ${ }^{1}$ Ministry of National Education, İbrahim Hoşver Middle School, Düzce, Turkey. \\ 2 Selçuk University Faculty of Sports Sciences, Konya, Turkey. \\ Address correspondence to T. Kaplan, e-mail: tkaplan@selcuk.edu.tr
}

\begin{abstract}
This study aimed to determine the leadership styles of boxing trainers. For this purpose, a total of 100 male trainers who worked actively in Turkey volunteered to participate in the study. The data of the study were collected by using the leadership questionnaire which was adapted by Tiryaki (2001) from the Leadership Scale for Sports (LSS) developed by Chelladurai and Saleh (1980). The descriptive statistical analysis of the obtained data was carried out using the Kruskal Wallis and MannWhitney-U tests. Whether the trainers were assigned to the national team, whether they differ in terms of age, how they were assigned, their training experience and level and their leadership styles were determined. After the tests were carried out, it was observed that there was a statistically significant difference between the variables of the trainers' age, training experience and level $(\mathrm{P}<0.05)$. Apart from the variables of age, training experience and level and the leadership style of democratic behavior, it was ascertained that there was no significant relationship between the leadership styles of the boxing trainers $(\mathrm{P}>0.05)$. According to the results of the study, the leadership styles of trainers do not differ according to whether they are/have been assigned as national team trainers. In addition, apart from democratic behavior, a significant difference was not detected in the other leadership styles in terms of demographic characteristics.
\end{abstract}

Keywords: Boxing, leadership, trainer.

\section{INTRODUCTION}

Although different meaning have been ascribed to the concept of leadership in all the fields that deal with management functions, this concept has always existed and maintained its importance since the most ancient ages of history. This concept that comes from the French word "leader" has the meaning of "Önder, Şef" in the Turkish Language Institution (TDK) (16). Leadership exists in all societies without discrimination of geography, religion or culture. Leadership is existent whenever and wherever people live within groups, communities or organizations and engage in activities. Therefore, it can be said that leadership is a humane, social and universal phenomenon. Nevertheless, despite the fact that it is a welldiscussed, written and investigated-field, it has stil not yet come to an agreement (7).

Leadership is a path walked with patience, a deepened activity of life, a paid off process rather than being a personal characteristics (12) Leadership is the ability and power of directing the behavior of the organization members towards the realization of its predetermined goals (3). A leader is not just an ordinary person. A leader must have the qualifications that puts an individual in the position of being a leader. Leaders should be able to move their followers in the direction they aim to go not just with their qualifications but also with their actions. It can be said that one has to first have a group/team accept his/her superior characteristics, then have these characteristics give confidence to them and get them to accept the impact in order to be considered as a leader (6).

Along with high performance, continuity in sport clubs also depends on the success. Along with performance, the builders of success are the leaders who make prudential plans for the team, have idiosyncratic methods in reaching goals and who are constantly with their athletes, getting to know them and satisfying their needs. A trainer comes forward as a leader who affects the group processes. Traditionally, a trainer is accepted as one who is inborn with charisma and leadership skills (1).

In this study that aimed to determine the leadership styles of boxing trainers; the leadership styles were analyzed with the variables of age, 
whether they were assigned to the national team, the level of training, years of experience and whether they were trainers of a national team.

\section{MATERIALS \& METHODS}

Trainers who work within the organization of the Turkish Boxing Federation were recruited for the study. A total of 100 trainers who participated in The Turkish Amateur Boxing (U15) Championship from May 27th to June 3rd in 2016 held in the province of Mersin, Turkey were randomly selected for this study.

The data collection consisted of two parts; a personal information form and a Leadership Scale for Sposts (LSS). The personal information form consisted of the participants' demographic characteristics. The form of leadership characteristics within the Leadership Scale for Sports (LSS), which was adapted to Turkish by Tiryaki \& Toros (14) and developed by Chelladurai \& Saleh (1980), was used in the study. The scale has been made up of 40 items for determining leadership styles that are divided into 5 subscales that determine the leadership styles entitled. Training and instruction behavior, Democratic behavior, Autocratic behavior, Social support behavior and Positive feedback behavior. Each response catagory was measured in a five-value Likert scale (5: Always, 4: Often, 3: Occasionally, 2: Seldom, and 1: Never). The scale's Cronbach Alpha internal consistency coefficients were given as follows; .79 for Training and instruction behavior, .79 for Democratic behavior, .56 for Autocratic behavior, .71 for Social support behavior and .65 for Positive feedback behavior.

\section{Analysis of the Data}

For descriptive statistics, the percentage distribution and frequency were used to organize and summarize the data. With the purpose of determining the statistical anlysis, testing for normality was carried out usig the KolmogorovSimirnow $Z$ Test $(z=.109, p<0.05)$. Because of the fact that the condition of normality distribution was not provided, in the analysis of the data, the Kruskal Wallis Test was performed for the multiple comparisons and the Mann-Whitney U Test for the paired comparisons. Statistical analyses were done through SPSS software, version 15.0 for Windows at the significance level of 0.05 .

\section{RESULTS}

The obtained results of the study have been given in the tables.

Table 1. Results of the leadership styles the trainers.

\begin{tabular}{lccccc}
\hline $\begin{array}{l}\text { Sub-Dimensions of } \\
\text { Leadership Styles }\end{array}$ & $\mathrm{N}$ & Mean & SD & Max & Min \\
\hline Training and Instruction & 100 & 4.32 & 0.25 & 4.73 & 3.67 \\
Democratic Behavior & 100 & 4.38 & 0.40 & 5.00 & 2.75 \\
Autocratic Behavior & 100 & 4.40 & 0.36 & 5.00 & 3.67 \\
Social Support & 100 & 4.09 & 0.45 & 4.75 & 3.00 \\
Positive Feedback & 100 & 3.72 & 0.33 & 4.50 & 2.83 \\
\hline
\end{tabular}

Table 2. Age distribution of the trainers.

\begin{tabular}{lcc}
\hline Age & N & $\%$ \\
\hline $21-30$ & 4 & 4.0 \\
$31-40$ & 26 & 26.0 \\
$41-50$ & 53 & 53.0 \\
$51-60$ & 17 & 17.0 \\
61 and above & 0 & 0.0 \\
Total & 100 & 100.0 \\
\hline
\end{tabular}

Table 3. Gender distribution of the trainers.

\begin{tabular}{ccc}
\hline Gender & $\mathrm{N}$ & $\%$ \\
Female & 0 & 0.0 \\
Male & 100 & 100.0 \\
Total & 100 & 100.0 \\
\hline
\end{tabular}

Table 4 . The results of whether the trainers are assigned to a national team.

\begin{tabular}{ccc} 
State of Being Assigned to a National Team & $\mathrm{N}$ & $\%$ \\
Yes & 71 & 71.0 \\
No & 29 & 29.0 \\
Total & 100 & 100.0 \\
\hline
\end{tabular}


Table 5. The distribution of the trainers according to their training level.

\begin{tabular}{ccc}
\hline Training Level & $\mathrm{N}$ & $\%$ \\
\hline 1 & 0 & 0.0 \\
2 & 16 & 16.0 \\
3 & 30 & 30.0 \\
4 & 28 & 28.0 \\
5 & 26 & 26.0 \\
Total & 100 & 100.0 \\
\hline
\end{tabular}

Table 6. The distribution of the tainers' years of experience.

\begin{tabular}{ccc}
\hline Training Experience (Years) & $\mathrm{N}$ & $\%$ \\
\hline $1-3$ & 0 & 0.0 \\
$4-7$ & 22 & 22.0 \\
$8-11$ & 12 & 12.0 \\
$12-15$ & 20 & 20.0 \\
15 and above & 46 & 46.0 \\
Total & 100 & 100.0 \\
\hline
\end{tabular}

Table 7. The distribution of whether the trainers are assigned to training a national team.

\begin{tabular}{ccc}
\hline State of Being a Trainer of a National Team & N & $\%$ \\
\hline Yes & 76 & 76.0 \\
No & 24 & 24.0 \\
Total & 100 & 100.0 \\
\hline
\end{tabular}

Table 8. The comparison of the trainers' leadership styles when they were athletes.

\begin{tabular}{|c|c|c|c|c|c|c|}
\hline $\begin{array}{l}\text { Sub-Dimensions of Leadership } \\
\text { Styles }\end{array}$ & $\begin{array}{c}\text { State of Being Assigned to a } \\
\text { National Team }\end{array}$ & $\mathrm{N}$ & Mean Rank & Sum of Ranks & $\mathrm{U}$ & $\mathrm{p}$ \\
\hline \multirow[t]{2}{*}{ Training and Instruction } & Yes & 71 & 50.83 & 3609.00 & \multirow{2}{*}{1006.00} & \multirow{2}{*}{.857} \\
\hline & No & 29 & 49.69 & 1441.00 & & \\
\hline \multirow[t]{2}{*}{ Democratic Behavior } & Yes & 71 & 53.20 & 3777.00 & \multirow{2}{*}{838.00} & \multirow{2}{*}{.142} \\
\hline & No & 29 & 43.90 & 1273.00 & & \\
\hline \multirow[t]{2}{*}{ Autocratic Behavior } & Yes & 71 & 48.33 & 3431.50 & \multirow{2}{*}{875.50} & \multirow{2}{*}{.224} \\
\hline & No & 29 & 55.81 & 1618.50 & & \\
\hline \multirow[t]{2}{*}{ Social Support } & Yes & 71 & 51.35 & 3646.00 & \multirow[t]{2}{*}{969.00} & \multirow{2}{*}{.644} \\
\hline & No & 29 & 48.41 & 1404.00 & & \\
\hline \multirow[t]{2}{*}{ Positive Feedback } & Yes & 71 & 49.41 & 3508.00 & \multirow{2}{*}{952.00} & \multirow{2}{*}{.550} \\
\hline & No & 29 & 53.17 & 1542.00 & & \\
\hline
\end{tabular}


Table 9. The comparison of the leadership styles the trainers prefer according to their training level.

\begin{tabular}{|c|c|c|c|c|c|}
\hline Sub-Dimensions of Leadership Styles & Training Level & $\mathrm{N}$ & Mean Rank & $\mathrm{X}^{2}$ & $\mathrm{p}$ \\
\hline \multirow[t]{5}{*}{ Training and Instruction } & 1 & 0 & - & .832 & .842 \\
\hline & 2 & 16 & 49.38 & & \\
\hline & 3 & 30 & 51.97 & & \\
\hline & 4 & 28 & 53.21 & & \\
\hline & 5 & 26 & 46.58 & & \\
\hline \multirow[t]{5}{*}{ Democratic Behavior } & 1 & 0 & - & 7.514 & .000 \\
\hline & 2 & 16 & 62.44 & & \\
\hline & 3 & 30 & 52.83 & & \\
\hline & 4 & 28 & 61.75 & & \\
\hline & 5 & 26 & 28.35 & & \\
\hline \multirow[t]{5}{*}{ Autocratic Behavior } & 1 & 0 & - & .440 & .932 \\
\hline & 2 & 16 & 54.63 & & \\
\hline & 3 & 30 & 50.30 & & \\
\hline & 4 & 28 & 49.57 & & \\
\hline & 5 & 26 & 49.19 & & \\
\hline \multirow[t]{5}{*}{ Social Support } & 1 & 0 & - & 2.208 & .530 \\
\hline & 2 & 16 & 45.19 & & \\
\hline & 3 & 30 & 46.23 & & \\
\hline & 4 & 28 & 54.61 & & \\
\hline & 5 & 26 & 54.27 & & \\
\hline \multirow[t]{5}{*}{ Positive Feedback } & 1 & 0 & - & 4.587 & .205 \\
\hline & 2 & 16 & 64.13 & & \\
\hline & 3 & 30 & 50.00 & & \\
\hline & 4 & 28 & 46.36 & & \\
\hline & 5 & 26 & 47.15 & & \\
\hline
\end{tabular}

According to Table 8, there was no significant difference in the comparisons made between the sub-dimensions of the trainers' leadership styles and whether they were assigned to a national team in their lives of sportsmanship ( $p>0.05$ ).

In result of the comparisons made between the sub-dimensions of the traing levels and leadership styles (Table 9), there was a statistically significant difference in democratic behavior $\left(X^{2}=7.514 ; \mathrm{p}<0.05\right)$. In result of the paired comparisons made by the Mann-Whitney U Test, carried out with the purpose of determining the group that the significant difference stemed from; it has been determined that there is a significant difference in favor of Level 2 trainers between Levels 2 and $5(\mathrm{U}=63.00$; $\mathrm{p}<0.05)$; there is a significant difference in favor of Level 3 trainers between Levels 3 and $5(\mathrm{U}=184.00 ; \mathrm{p}<0.05)$ and there is a significant difference in favor of Level 4 trainers between Levels 4 and $5(\mathrm{U}=139,00 ; \mathrm{p}<0.05)$ $(p>0.05)$. The differences between the other groups were not found to be statistically significant ( $p>0.05)$.

According to Table 10, there was a significant difference found in democratic behavior $\left(X^{2}=13.898\right.$; $\mathrm{p}<0.05)$ in the statistical analysis between the subdimensions of training experience and leadership styles. In result of the paired comparisons made with the Mann-Whitney U Test, carried out with the purpose of determining the group in which the significant difference in democratic behavior is; there was a significant difference in favor of the trainers with 4-7 years of experience between 4-7 years and 15 years of experience $(U=326.00 ; p<0.05)$; 
there was a significant difference in favor of the trainers with 8-11 years of experience between 8-11 years and 12-15 years of experience $(U=58.00$; $\mathrm{p}<0.05)$; there was a significant difference in favor of the trainers with 8-11 years of experience between 811 years and 15 years of experience ( $U=109.00$; $\mathrm{p}<0.05)$. The differences among the other groups were found to be statistically not significant $(p>0.05)$.

There was no significant difference found in the comparison made between the sub-dimensions of whether the trainers are assigned in training a national team and the leadership styles $(p>0.05$; Table 11).

According to Table 12, in result of the statistical analysis of the comparison made between the sub- dimensions of age and the leaderships of the trainers who participated in the study, it was observed that there was a significant difference in democratic behavior $\left(X^{2}=11.396 ; p<0.05\right)$. In result of the paired comparison made with the Mann-Whitney U Test, carried out with the purpose of determining the group in which the significant difference in democratic behavior is; there was a significant difference in favor of the 31-40 year old trainers between the trainers of 31-40 and 41-50 years of age ( $U=432.00 ; p<0.05)$; there was a significant difference in favor of the 31-40 year old trainers between the trainers of $31-40$ and $51-60$ years of age ( $U=118.00$; $\mathrm{p}<0.05)$. The differences among the other groups were found to be statistically not significant $(p>0.05)$.

Table 10. The comparison of the leadership styles the trainers prefer in accordance with their training experiences.

\begin{tabular}{|c|c|c|c|c|c|}
\hline Sub-Dimensions of Leadership Styles & Training Experience (Years) & $\mathrm{N}$ & Mean Rank & $X^{2}$ & $\mathrm{p}$ \\
\hline \multirow[t]{5}{*}{ Training and Instruction } & $1-3$ & 0 & - & & \\
\hline & $4-7$ & 22 & 54.91 & & \\
\hline & $8-11$ & 12 & 64.92 & 5.367 & .147 \\
\hline & $12-15$ & 20 & 50.30 & & \\
\hline & 15 and above & 46 & 44.72 & & \\
\hline \multirow[t]{5}{*}{ Democratic Behavior } & $1-3$ & 0 & - & & \\
\hline & $4-7$ & 22 & 58.59 & & \\
\hline & $8-11$ & 12 & 73.25 & 13.898 & .003 \\
\hline & $12-15$ & 20 & 48.75 & & \\
\hline & 15 and above & 46 & 41.46 & & \\
\hline \multirow[t]{5}{*}{ Autocratic Behavior } & $1-3$ & 0 & - & & \\
\hline & $4-7$ & 22 & 52.86 & & \\
\hline & $8-11$ & 12 & 67.17 & 6.105 & .107 \\
\hline & $12-15$ & 20 & 43.30 & & \\
\hline & 15 and above & 46 & 48.15 & & \\
\hline \multirow[t]{5}{*}{ Social Support } & $1-3$ & 0 & - & & \\
\hline & $4-7$ & 22 & 58.41 & & \\
\hline & $8-11$ & 12 & 46.25 & 5.142 & .162 \\
\hline & $12-15$ & 20 & 57.90 & & \\
\hline & 15 and above & 46 & 44.61 & & \\
\hline \multirow[t]{5}{*}{ Positive Feedback } & $1-3$ & 0 & - & & \\
\hline & $4-7$ & 22 & 47.27 & & \\
\hline & $8-11$ & 12 & 59.17 & 4.505 & .212 \\
\hline & $12-15$ & 20 & 40.60 & & \\
\hline & 15 and above & 46 & 54.09 & & \\
\hline
\end{tabular}


Table 11. The comparison of leadership styles the trainers prefer according to whether they are assigned to training a national team.

\begin{tabular}{|c|c|c|c|c|c|c|}
\hline Sub-Dimensions & Being National Team & $\mathrm{N}$ & Mean Rank & Sum of Ranks & $\mathrm{U}$ & $\mathrm{p}$ \\
\hline \multirow[t]{2}{*}{ Training and Instruction } & Yes & 76 & 49.88 & 3791.00 & \multirow{2}{*}{865.00} & \multirow{2}{*}{.703} \\
\hline & No & 24 & 52.46 & 1259.00 & & \\
\hline \multirow[t]{2}{*}{ Democratic Behavior } & Yes & 76 & 51.84 & 3940.00 & \multirow{2}{*}{810.00} & \multirow{2}{*}{.406} \\
\hline & No & 24 & 46.25 & 1110.00 & & \\
\hline \multirow[t]{2}{*}{ Autocratic Behavior } & Yes & 76 & 48.97 & 3722.00 & \multirow{2}{*}{796.00} & \multirow{2}{*}{.330} \\
\hline & No & 24 & 55.33 & 1328.00 & & \\
\hline \multirow[t]{2}{*}{ Social Support } & Yes & 76 & 50.42 & 3832.00 & \multirow{2}{*}{906.00} & \multirow{2}{*}{.961} \\
\hline & No & 24 & 50.75 & 1218.00 & & \\
\hline \multirow[t]{2}{*}{ Positive Feedback } & Yes & 76 & 48.93 & 3719.00 & \multirow{2}{*}{793.00} & \multirow{2}{*}{.330} \\
\hline & No & 24 & 55.46 & 1331.00 & & \\
\hline
\end{tabular}

Table 12. The comparison of the leadership styles the trainers prefer according to their age.

\begin{tabular}{|c|c|c|c|c|c|}
\hline Sub-Dimensions & Age & $\mathrm{N}$ & Mean Rank & $X^{2}$ & $\mathrm{p}$ \\
\hline \multirow[t]{5}{*}{ Training and Instruction } & $21-30$ & 4 & 75.50 & 6.193 & .103 \\
\hline & $31-40$ & 26 & 54.81 & & \\
\hline & $41-50$ & 53 & 50.11 & & \\
\hline & $51-60$ & 17 & 39.24 & & \\
\hline & 61 and above & 0 & - & & \\
\hline \multirow[t]{5}{*}{ Democratic Behavior } & $21-30$ & 4 & 71.00 & 11.396 & .010 \\
\hline & $31-40$ & 26 & 64.04 & & \\
\hline & $41-50$ & 53 & 45.42 & & \\
\hline & $51-60$ & 17 & 40.82 & & \\
\hline & 61 and above & 0 & - & & \\
\hline \multirow[t]{5}{*}{ Autocratic Behavior } & $21-30$ & 4 & 68.50 & 2.304 & .512 \\
\hline & $31-40$ & 26 & 50.12 & & \\
\hline & $41-50$ & 53 & 51.03 & & \\
\hline & $51-60$ & 17 & 45.21 & & \\
\hline & 61 and above & 0 & - & & \\
\hline \multirow[t]{5}{*}{ Social Support } & $21-30$ & 4 & 84.75 & 7.020 & .071 \\
\hline & $31-40$ & 26 & 54.08 & & \\
\hline & $41-50$ & 53 & 47.77 & & \\
\hline & $51-60$ & 17 & 45.47 & & \\
\hline & 61 and above & 0 & - & & \\
\hline \multirow[t]{5}{*}{ Positive Feedback } & $21-30$ & 4 & 58.50 & 4.163 & .244 \\
\hline & $31-40$ & 26 & 42.65 & & \\
\hline & $41-50$ & 53 & 55.23 & & \\
\hline & $51-60$ & 17 & 45.88 & & \\
\hline & 61 and above & 0 & - & & \\
\hline
\end{tabular}




\section{DISCUSSION}

It has been understood from the data that most of the trainers who participated in the study have the leadership style of autocratic behavior. Autocratic behavior was followed by, in order, democratic behavior, training and instruction, social support and then positive feedback (Table 1). In a study on Taekwondo trainers, it was determined that, in order, the trainers were inclined to the leadership styles of democratic behavior, training and instruction, autocratic behavior, social support and positive feedback (17). The leadership styles of trainers may differ according to external factors and the qualities of the athletes they are working with. Therefore, it is not suitable to judge the trainers' leadership styles as good or bad. The essential thing for the trainers is to be aware of their leadership styles and be able to make changes in their leadership styles in accordance with the qualities of the athletes (13).

The age ranges of the trainers who participated in the study have been given (Table 2). Köksal (11) has determined that the trainers of individual sports are $36 \%$ at the range of $31-40$ years of age and $25 \%$ at the range of 41-50 years of age. Çelik (5), in a study on soccer trainers, has reported that $24 \%$ are at the range of $41-45$ years of age and $75 \%$ are at the range of 36 years and above. In this sense, it can be concluded that trainers are young and middle-aged individuals.

There was no significant difference among the sub-dimensions of democratic behavior in the leadership styles of the trainers in accordance with age. According to the obtained data, it can be said that the more the age decreases, the more the trainers are inclined to the leadership style of democratic behavior (Table 12). Yurt (17) has reported that, with Taekwondo trainers, apart from autocratic behavior, there was no significant difference between the leadership styles according to age. The significant difference found in autocratic behavior was reported to be in favor of trainers between the ages of 41-50. The findings of the study are supportive of each other although there seems to be a contradiction. Hasançebioğlu (8) has come to conclusion that the leadership styles of teachers do not differ with age. Karayol (10) has observed that there is no significant difference between the age groups and leadership style scores.

It has been observed that all of the trainers who participated in the study are male individuals and there are no female individuals among them (Table 3). In a study on individual sports trainers, it has been observed that $22 \%$ were female, $78 \%$ were male and that leadership styles do not differ according to gender (11). Hasançebioğlu (8) has also reported similar results. In the study Birell and Cole (2) carried out in America, they have determined that the rate of female trainers, who train male athletes for individual and team sports, is $1 \%$. Based on results of studies, it can be accepted that male individuals are dominant in the profession of sports training.

It has been observed that $71 \%$ of the trainers who participated in the study have experienced a national sportsmanship (assignment) (Table 4). A significant difference was not found in the subdimensions of the leadership styles of the trainers who have or have not experienced national sportsmanship in their career (Table 8). Yurt (17) has obtained similar results for Taekwondo trainers. A trainer's part in an athlete's success and performance is related to his/her previous experiences in terms of sports, special learned skills, culture, physical conditions and working environment, dealing with the athletes, motivation and compliance (4). In this sense, it can be said that the trainers' previous life in terms of sports has a direct effect on athletes' performances.

The training levels of the trainers who participated in the study have been given in Table 5 . In a study, it has been observed that $53.1 \%$ of tenis trainers were in level $1,30.5 \%$ in level $2,14.1 \%$ in level 3, 1.7\% in level 4 and $0.6 \%$ in level 5 (15). Similarities or differences in training levels is a natural result. Apart from democratic behavior, a significant difference has not been observed among the leadership styles of the boxing trainers, who participated in the study, regarding training levels (Table 9). In accordance with the obtained results of the study, the more the training level decreases, the more the trainers are inclined to the leadership style of democratic behavior. A study on tenis trainers has reported that there was no significant difference between self-sufficiency situations as well as leadership styles and training levels (15).

The fact that approximately half of the trainers have 15 years and above of experience in training really draws attention (Table 6). In a study on individual and team sports trainers, it has been determined that most trainers have between 6 to 10 years of experience in training (9). According to the 
study results, it can be said that trainers have medium and high levels of experience.

No significant difference was observed in the leadership styles the boxing tainers preferred according to the groups of their training experiences (Table 10). According to these data, it can be said that the more the training experience decreases the more trainers are inclined to the leadership style of democratic behavior. A significat difference has been detected between the tennis trainers' leadership styles of social support and positive feedback and their active training period. The scores of the leadership styles of trainers whose active training periods are 4-6 years, were found to be significantly high (15). It has been reported that there was no significant difference between the scores of the leadership styles of trainers of male team sports in accordance with their experiences of being team captains (10).

$76 \%$ of the trainers who participated in the study have worked as a national team trainer (Table 7). No significant difference was obtained in the comparisons made between the sub-dimensions of whether they have been assigned as a national team trainer and their leadership styles (Table 11). To our knowledge, there was no report on national team training and leadership styles in the obtained literature.

In the study, it has been observed that trainers between the ages of 31-40, who are level 2 trainers and who have between 4-7 years of experience display more democratic behavior when compared to the other trainers. According to the results of the study, the leadership styles of trainers do not differ according to whether they are/have been assigned as national team trainers. In addition, apart from democratic behavior, a significant difference was not detected in the other leadership styles in terms of demographic characteristics. The fact that the trainers who participated in the study were all male individuals prevented the leadership styles to be tested in accordance with the variable of gender.

To perform more comprehensive studies with larger sample sizes on boxing trainers is important in terms of generating data and evaluation. A difference in three demographic characterictics has been detected in democratic behavior which are; the level of training, experience of training and age. While no differences were observed in the other leadership styles, the difference observed in democratic behavior is considered as a matter that needs to be further investigation and is thought that it could contribute to the field. The fact that most of the participant trainers have the leadership style of autocratic behavior is a subject to be embarked on in terms of the sport of boxing. Additionally, another subject of interest would be the fact that there is male dominance among boxing trainers.

\section{REFERENCES}

1. Ahola SE, Hatfield B. Psychology of Sports. Iowa: Brown Publisher, 1986.

2. Birell S, Cole CL. Women Sport and Culture, Canada: Human Kinetics, 1994.

3. Bursalığlu Z. Okul Yönetiminde Yeni Yapı ve Davranış, Ankara: Ankara Üniversitesi, Eğitim Fakültesi Yayınları, 1987.

4. Casey G. What is takestobecome a winning coach. Coach and Athletic Director, 2004: 36-74.

5. Çelik VO. Amatör Futbol Antrenörlerinin Liderlik Özellikleri Üzerine Bir Araştırma. Yayınlanmamış Yüksek Lisans Tezi, Anadolu Üniversitesi Sağlık Bilimleri Enstitüsü, Eskişehir, 2005.

6. Güney S. Yönetim ve Organizasyon, Ankara: Nobel yayınları, 2001

7. Gündüz H, Beşoluk Ş, Önder İ. Karmaşık Sistemlerde Liderlik Bakışıyla: Dna Liderlik. Uluslararası İnsan Bilimleri Dergisi, 2011; 8(1): 520-544.

8. Hasançebioğlu T. Öğretmenlerin Liderlik Stilleri, Bilgisayar Tutumları ve Aralarındaki İlişkilerin İncelenmesi. Yayınlanmamış Yüksek lisans Tezi, Marmara Üniversitesi Eğitim Bilimleri Enstitüsü, İstanbul, 2002.

9. İmamoğlu R. Bazı takim ve ferdi spor branşlarindaki antrenörlerin iş tatmin düzeylerinin incelenmesi üzerine bir araştirma. Yayınlanmamış Yüksek Lisans Tezi, Gazi Üniversitesi, Sağlık Bilimleri Enstitüsü, Ankara, 2001.

10. Karayol M. Takım sporları ve doğa sporları yapan erkek sporcuların liderlik özelliklerinin incelenmesi. Yüksek Lisans Tezi, İnönü Üniversitesi Sağlık Bilimleri Enstitüsü, Malatya, 2013.

11. Köksal F. Liderlik Tarzları ve Antrenörlük. Yüksek Lisans Semineri, Selçuk Üniversitesi Sağlık Bilimleri Enstitüsü, Konya, 2007.

12. Sadler P. Leadership. Kogan Page, London, 1997.

13. Temel V. Konya iline ait bireysel ve takım sporu antrenörlüğü yapan bireylerin liderlik tarzlarının karşılaştırılması. Yüksek lisans tezi, Karamanoğlu Mehmetbey Üniversitesi Sosyal Bilimler Enstitüsü, Karaman, 2010.

14. Tiryaki S, Toros Z. Spor için liderlik ölçeği, koçun kendi lider davranışını algılaması formunun geçerlik ve güvenirlik çalışması. II. Uluslar arası Spor Psikolojisi Sempozyumu, 1112 Ekim, İzmir, 2001.

15. Toklu O. Tenis antrenörlerinde liderlik özellikleri ve öz yeterlilik arasındaki ilişkinin belirlenmesi. Yüksek Lisans Tezi, Selçuk Üniversitesi Sağlık Bilimleri Enstitüsü, Konya, 2010 . 
16. Yıldırım BN. Liderlik özellikleri ve liderlik tarzlarinin duygusal zeka perspektifinden incelenmesi. Yüksek Lisans Tezi, Kocaeli Üniversitesi, Sosyal Bilimler Enstitüsü, Kocaeli, 2012.
17. Yurt O. Tekvando antrenörlerinin liderlik tarzlari. Yüksek Lisans Tezi, Selçuk Üniversitesi Sağlık Bilimleri Enstitüsü, Konya, 2009. 